CATALAN REVIEW

Catalan Review

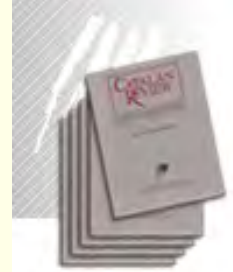

You are accessing the Digital Archive of the Catalan Review Journal.

By accessing and/or using this Digital Archive, you accept and agree to abide by the Terms and Conditions of Use available at http://www.nacs-

catalanstudies.org/catalan review.html

Catalan Review is the premier international scholarly journal devoted to all aspects of Catalan culture. By Catalan culture is understood all manifestations of intellectual and artistic life produced in the Catalan language or in the geographical areas where Catalan is spoken. Catalan Review has been in publication since 1986.
NORTH

AMERICAN

CATALAN

SOCIETY
Esteu accedint a l'Arxiu Digital del Catalan Review

A l' accedir i / o utilitzar aquest Arxiu Digital, vostè accepta i es compromet a complir els termes i condicions d'ús disponibles a http://www.nacs-

catalanstudies.org/catalan review.html

Catalan Review és la primera revista internacional dedicada a tots els aspectes de la cultura catalana. Per la cultura catalana s'entén totes les manifestacions de la vida intel lectual i artística produïda en llengua catalana o en les zones geogràfiques on es parla català. Catalan Review es publica des de 1986.

\title{
The Reason Behind Food of Love: Some comments about bringing, through my catalan eyes and a group of exceptional British actors, an American novel to the screen Ventura Pons
}

Catalan Review, Vol. XVIII, number 1-2, (1998), p. 237-248 


\title{
THE REASON BEHIND FOOD OF LOVE:
}

\author{
SOME COMMENTS ABOUT BRINGING, \\ THROUGH MY CATALAN EYES AND A GROUP \\ OF EXCEPTIONAL BRITISH ACTORS, \\ AN AMERICAN NOVEL TO THE SCREEN
}

\section{VENTURA PONS}

\begin{abstract}
Ventura Pons, arguably the most important film director in the Catalan language (and one of the most important directors in European cinema in general), provides an intimate look into the inspiration, conceptualization, and realization of Food of Love. Besides being one of the director's rare ventures into the English language, Food of Love is also, as is often the case with Pons, an adaptation of a prior literary work, here David Leavitt's The Page Tumer. Struck by the force of a story of love, sex, and ambition among men, Ventura Pons grapples with questions that go beyond the gay U.S. context in which the story is originally set and that bear on some of the more affective aspects of the interaction of people in the so-called Western world: questions of personal integrity and fulfillment, of desire and disillusionment, of "sentimental education" and family ties.
\end{abstract}

All films are concerned with telling a story. The better the story, the better the film. Each project I have directed has always been a pleasure, a fascination, a passion, and a necessity of mine to explain, implicate, and submerge myself profoundly in the stories I choose. It is impossible for me to understand filmmaking in any other way. All of these feelings reemerged in and as Food of Love.

Food of Love is a film based on The Page Turner by David Leavitt, a novel that was originally published in the United States in 1998 by the Boston publishers, Houghton Mifflin. I became acquainted with the text when the Spanish language version titled, Junto al pianista, was published in April 2000 by Anagrama. Nevertheless, my interest in Leavitt as an author was by no means new; in fact, it had lasted for more than a decade-although it is hard to believe that fifteen years have passed since his first publications. Perhaps I should pause to explain the reason behind my interest.

I became familiar with Leavitt's first work, a book of short stories 
titled Family Dancing, as soon as it was published; David Schor, a friend of mine from New York and a professor at Wesleyan University with whom I was traveling through Egypt gave me the book in Cairo. $\mathrm{He}$ was extremely proud of the young Leavitt, who had been a brilliant student of his and was making a sensational debut as a writer. Indeed, Leavitt's first book was a finalist for both the National Critics Circle Awards and for the PEN/Faulkner Prize. I, for my part, devoured the book; Leavitt's stories had something special. Through them I perceived a world that was not only close, despite our geographic distance, but also identifiable and, at the same time, extremely cinematographic. Since then, whenever I have read one of Leavitt's works, I have felt a thematic closeness, but above all, I have perceived them according to this vision of mine that stimulates and conditions my profession. Although Leavitt's stories were set in the United States, and only later in Europe, I felt a very personal connection with them. The things he described, the behavior he portrayed, the morality and customs of a shared Western civilization were familiar and immediately recognizable - I suppose, for obvious reasons, principally due to the influence of United States in the world of cinema.

Before long, Leavitt left more than one person in open-mouthed surprise with his second book, The Lost Language of Cranes. This dense, engaging, and poignant novel confirmed Leavitt's place as a prestigious author and was brought to the cinema in 1991 in an adaptation produced by the BBC and directed by Nigel Finch. It was clear to me that somebody else had also been able to see the cinematographic possibilities of Leavitt's work. Between the publication of this book and the shooting of the film, Leavitt spent a year in Barcelona, my city, on a grant from the Institució de les Lletres Catalanes. Upon his arrival, he telephoned me - as my friend from the United States had told him about me- and during several weeks I helped him to settle into life in the city, something that he was quick to do. However, after this initial period, I saw him rarely. Since then, we have met occasionally in New York in the home of mutual friends.

A decade passed - a decade of much work for both of us - until I discovered Leavitt's The Page Turner. The feelings that I had experienced years before while reading his first book emerged again. The meaning was crystal clear to me. The story, and the world described by Leavitt in it, would allow me to progress along the road which attracted me so much and which is nothing other than the opportunity to combine my filmmaking with the themes that emanate from our generational, social, and cultural environment.

Why can people not have what they want? How does a lack of sentimental education affect young homosexuals in the Western World? 
Is it really so easy for life to corrupt you if you are not on your guard? Is it honest if one does not fight hard to achieve one's own personal fulfillment? What is the price, and what is the meaning, of "personal integrity" in a society like ours? The force and originality that I found in The Page Turner stems from the fact that these aforementioned questions go far beyond the gay and North American context in which they are set. The story portrays a microcosm, which is at once tragic and comic, intense and light-hearted, transparent and complex, wise and naive, mature and tender, but above all universally moving.

The novel immediately inspired me to make a very personal cinematographic translation. When I wrote the screenplay, I changed the trip taken by the main characters from Rome to Barcelona, without allowing the change to diminish in any way the emotional impact that the geographical setting has on the narrative. I also allowed myself the liberty of making Kennington, one of the main characters, British instead of American and of providing a new title, which comes, obviously enough, from the lines that Orsino utters at the opening of Shakespeare's Twelfth-Night:

If music be the food of love, play on;

Give me excess of it, that, surfeiting,

The appetite may sicken, and so die.

That strain again! It had a dying fall:

$\mathrm{O}$ ! it came o'er my ear like the sweet sound

That breathes upon a bank of violets,

Stealing and giving odour. - Enough! No more:

' $T$ is not so sweet now, as it was before. (289)

I based the action not only on Paul's awakening of the adult world but also the awakening to a new life that is experienced by Pamela, his mother, a woman disturbed by the collapse of a world that she had believed to be solidly established - a disturbance heightened by her discovery of her son's sexual orientation. What interested me, first in the book and later in my translation of it to the screen, was, on the one hand, the world in construction of Pamela and her son and, on the other, the established world of the pianist and his manager. Together, they comprise two opposing yet complimentary worlds, neither of which is simply pure or villainous. Indeed, I believed that the essence of the story lay in the various nuances of the main character's motives. It appeared to me that it was necessary to present them in the simplest manner possible; to do so, I submerged myself in the "interior" of the four main characters where so much truth was contained for dissection.

I find it hard to define my style of filmmaking. Then again, I do not believe that I am the most suitable person to do so. I always seek 
personal themes that affect me greatly and that allow for, and adhere to, a very personal style. The stories that I choose are neither easy nor conventional; they always contain some implicit risk. They are stories that are based mainly on characters, part and parcel of the great pleasure that I derive from working with actors. After all, I am from the school of acting, characters, and words; my theatrical roots are, in some sense, always present in my mind. Perhaps not surprisingly, I have always liked directors as varied as Mankiewicz, Rohmer, or Woody Allen. If Allen is attracted by the urban landscape of New York, I am attracted by the urban landscape of my city, Barcelona. After making so many films, it is clear to me that there is a profound relationship between the city of Barcelona and my work. I am interested, moreover, in a city of losers, not, as is so often the case, in one of winners, As a result, my films go against the grain, as dominant cinema feeds on dreams of success and promotes escapism. Whatever the case, I end up exploring themes that have to do with the need for love, for communication, for finding one's proverbial other half. That we all, deep down, need each other is very important to me, though I am fully aware that, at times, many people speak about this with a certain flippancy and frivolity. I realize that I always contemplate essentially the same themes.

Food of Love is not only a story that I enjoy but also one that works very well within the framework of the type of films that I like to make: films that are largely character-based and that allow me to work with a strong cast of actors who come mainly from the world of the theatre. When directing, I consider mutual understanding with the cast to be absolutely necessary. I like to discuss with them the details, especially as they relate to the motives of the characters that we together create. I firmly believe that the actors' theatrical discipline helps me immensely to construct the films that I direct,

A film is made up of three elements: the story, the mise-en-scène, and the cast. If these elements do not work well together, or if even one of them fails, the final result will be more than suspect. Food of Love, which I had the good fortune to cast with exceptional British actors, has strong performances guaranteed by the solid professionalism of all the cast, including its younger members. I believe that the input of these actors - Juliet Stevenson (who plays Pamela), Paul Rhys (who plays Kennington), Allan Corduner, Geraldine McEwan, and the young Kevin Bishop (who plays Paul) - gives the film an interest which issues from their recognized talent as performers and not from excessive, and in my opinion, unnecessary production costs.

The basis for the mise-en-scène of cinema is conceptual, and it is the director who gives it meaning. In a feature film, all of those involved follow a concept that unites and gives meaning to the various elements: 
lighting, set design, acting, pace, music, editing, all of which must be in agreement with the director's basic concept. I am not in favor of beginning to work before I have everything quite clear, for I consider that the cinematic profession requires much reflection that must be done well in advance of the principal photography. One of the things that I have learnt is to follow the concept through until the end - for better or for worse. I would like to think that this is one of the attractive things of my films. It is not just a question of thematic risks, but also of narrative risks, which I always follow through.

Food of Love needs to be explained chronologically. I am quite aware of my penchant for - and delight in - telling stories in a nonlinear or chronologically discontinuous manner and for minimalist friezes, as in some of my most recent films: El perquè de tot plegat [What It's All About], Caricies [Caresses], and Morir (o No) [To die (Or not)]. However, I believe that the narrative concept must serve the best interests of the story and not the other way around. In the case of Food of Love, the narrative concept required a chronological presentation and a fairly simple, straightforward treatment.

I have always defended a cinema in which quality and creativity take place of pride, a cinema based on concepts and content rather than high production costs. I think that I was able to realize all of the hopes that inspired me to begin Food of Love.

I would like to believe that those who have followed my previous thirteen productions with proven interest, as well as the many worldwide readers of David Leavitt (who would surely be intrigued by the second film adaptation of one of his novels), understood and enjoyed this project in which we invested so many hopes and so much happiness.

\section{A FEW NOTES ON MY TREATMENT OF THE MATERIAL (WRITTEN BEFORE SHOOTING THE FILM)}

\section{One}

Paul is eighteen and believes that he is abour to begin a spectacular career as an international concert pianist. His belief is supported by his mother, Pamela, and by his music teacher, who considers him a star pupil. His hero is Kennington, an established star, whose recordings Paul collects obsessively. To his joyful surprise, Paul is invited to be the page turner at one of Kennington's concerts. On stage, the nervous young devotee is only interested in turning the pages efficiently, and in being close to his hero. Kennington, on the other hand, is distracted by the handsome boy who so diligently assists him. Kennington's 
manager, Mansourian, watching from the wings, also appreciates the boy's charms.

A few weeks later, and completely our of the blue, Paul's father leaves his family for a girl from his office, and Paul agrees to accompany his emotionally distraught mother, Pamela, on a holiday to Barcelona.

\section{Notes to \# I:}

The first act, of the five in which the action is divided, serves to introduce the four main characters and to begin to define their world and their underlying motivations. Paul'sdreams of a brilliant future, shared by bis mother, stand in stark contrast with the apparently jaded attitude of Kennington and his agent, Mansourian, and quickly help us establish a sense of two different worlds: one under construction and the other already firmly established.

The act ends with the unexpected news of Paul's father's infidelity and departure. Although we never see Paul's father, his off-screen presence conditions many of the events that follow - and not merely those that concern Pamela, who here experiences the first dramatic twist in the film and so becomes one of the most intense and complex characters of the story. Will the lack of a father figure in Paul's life heighten his attraction to Kennington? Is Paul looking for a father or a lover? For that matter, is Kennington and Mansourian's relationship also like that of father and son instead of two equal lovers? As the story develops in the following acts, we come to know three men separated by generations but united by sex.

\section{Two}

When Paul and Pamela arrive in Barcelona she is somewhat jet-lagged but he is desirous to explore the city. In his tour of Barcelona's famous modernist buildings, he promptly comes across the impressive and ornate Palau de la Música Catalana, where he sees a poster announcing a performance by Kennington - for the night before Paul's arrival. Paul tracks Kennington down and goes to his hotel in order to see his idol and perhaps even to spend some time with him, away from Paul's overbearing mother. Paul and Pamela are going through a moment of difficult transition, when the teenager wants to break free and become independent, while his mother, who is feeling depressed after the break-up of her marriage and who is suffering from a typical mid-life crisis, needs him more than ever.

Kennington is weary of the demands of his concert tour and the 


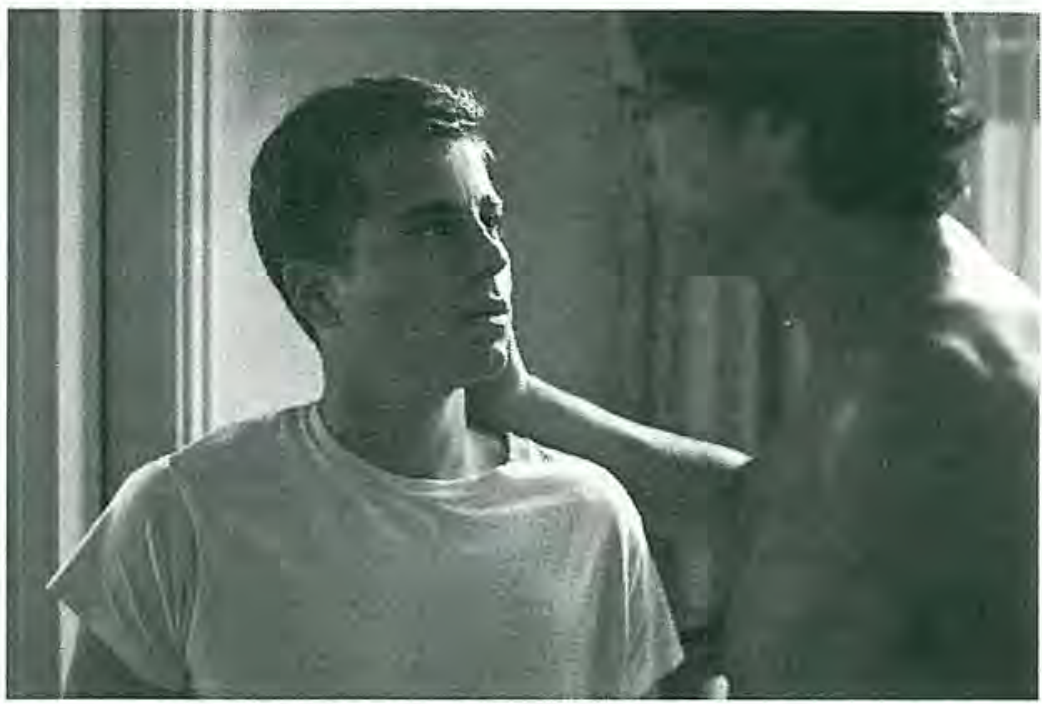

Kevin Bishop as Paul and Paul Rhys as Kennington

endless succession of trivial messages that his long-time boyfriend and agent, Mansourian, sends him from New York. Mansourian, a successful musical agent respected worldwide, is sixty years old and a celebrity in his own right. Their relationship is solid, and they share a liberal understanding that when the cat is away the mouse will play, or as they say in the film industry "DCOL": infidelity "does not count on location." Therefore, Kennington initially sees the sudden appearance of Paul as merely a pleasant distraction. The boy is surprised by Kennington's lack of interest in talking about music and his lack of satisfaction with his international celebrity. Paul remains nonetheless in awe of his idol, and is delighted when their mutual attraction develops rapidly after their first meeting. What begins as a light-hearted fling for Kennington quickly becomes more serious; he appears to be on the brink of falling in love with the boy. The messages from Mansourian continue to arrive almost continuously, but they go unanswered. To Kennington, his life in New York seems very far away.

The affair between Kennington and Paul remains a secret from Pamela who believes the two are off sightseeing and studying Modernist art in the city. Her time alone allows her to re-discover herself, and she slowly begins to feel attractive again. While Kennington is enjoying the forbidden fruit of Pamela's son, Pamela herself is discovering the joys of running up her ex-husband's credit cards in expensive designer clothing stores. Her combination of 


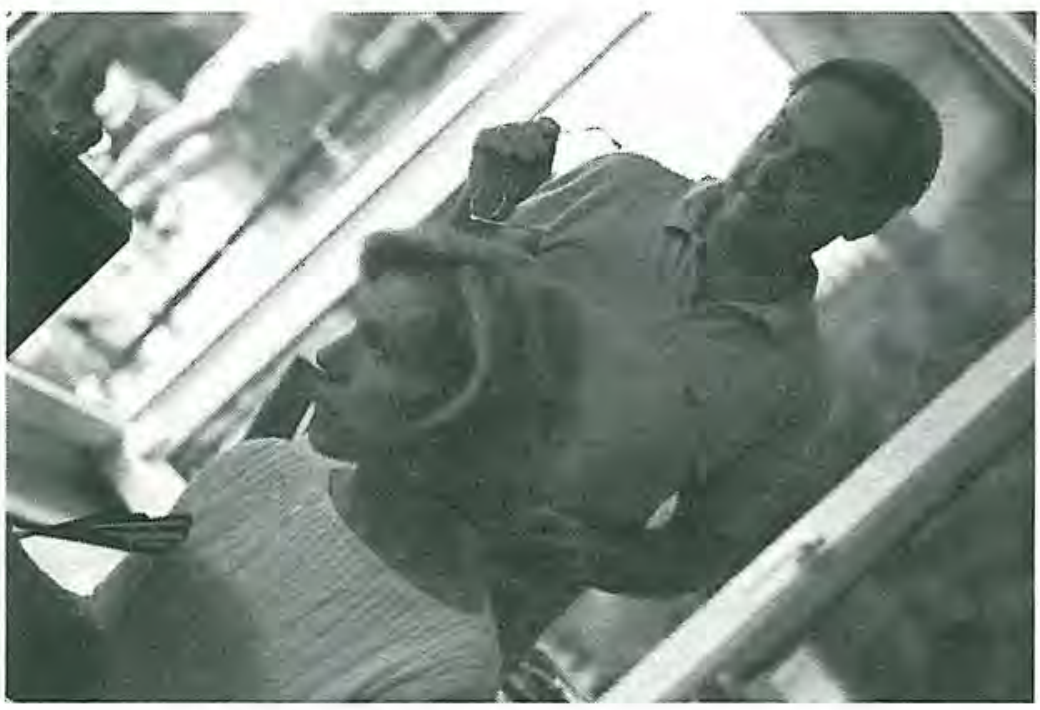

Juliet Stevenson as Pamela with director Ventura Pons

innocence and newly found self-confidence leads her to believe that Kennington is only taking an interest in her son's cultural education as a means of courting her; an idea that vanishes when she visits Kennington in his room and, despite her overtures, finds him to remain completely unmoved. When she discovers what appear to be her son's underwear in the bathroom, she backs off, and although not wanting to accept reality, abandons her clumsy seduction.

Kennington, realizing the mess that he is creating abruptly wakes up to reality and reacts cowardly. His only wish is to return to Mansourian and his established life in New York as quickly as possible; he takes the first plane available without saying goodbye. As far as he is concerned, Paul and Pamela are now a closed chapter.

\section{Notes to \# 2:}

The Mediterranean light will be the frame for the second act, which narrates Paul's awakening to love, sensuality, and the joys of a seemingly reciprocal relationship. The boy not only discovers a fascinating older culture, but also a person -Kennington, his artistic idol-who awakens deep feelings in him, feelings that he is experiencing for the first time in his life. Paul's awakening takes place while his mother, Pamela, who 
is still traumatized by the recent failure of her marriage, remains oblivious to what is happening in her son's life.

For Kennington, a man used to life at the top, the affair with young Paul also has a profound meaning that be has perbaps not experienced for years, although the viewer now discovers the solid relationship between him and Mansourian, his manager and long-time lover. Kennington bebaves cowardly when faced with the growing responsibility imposed by bis affair with the boy. Pamela's behavior, as an uncomprehending woman, is a determining factor in Kennington's rejection of his budding relationship and his abrupt departure.

A fascinating place, Barcelona provides the backdrop for the filming of all this turbulence between the three foreigners. As the audience is treated to the light, the texture, and the beauty of the city, the emotions of the trio grow in a controlled crescendo that will be interrupted at the act's finale: Kennington's escape to New York.

\section{Three}

That autumn, as planned, Paul enrolls in Julliard, the prestigious New York music academy. He resists the temptation to contact Kennington, who lives in the same city. Almost immediately, he discovers that his youthful dreams will not be realized. He lacks both the skill

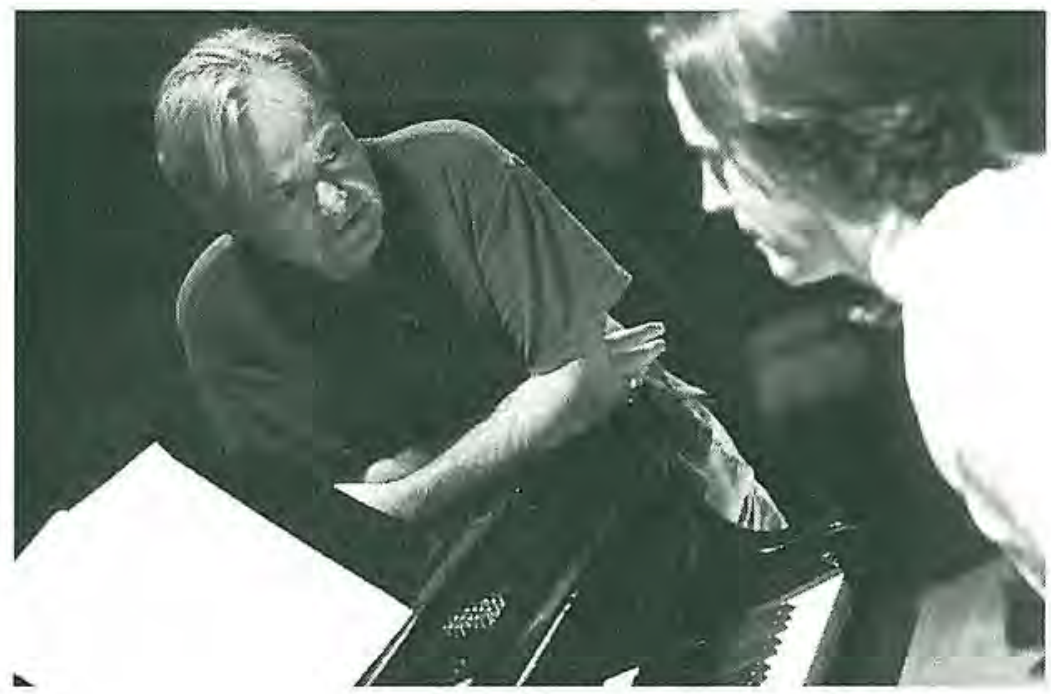

Ventura Pons directs Paul Rhys 
and the star quality to become a great concert pianist; as his seasoned teacher so flatly puts it, his talent is only sufficient for him to accompany others. This sobering realization carries over to his personal life. $\mathrm{He}$ has started a new relationship with Alden, another successful man in his forties. Their relationship seems comfortable, but the passion of Alden's life is a previous lover who has passed away.

Paul's disappointment about his life and his limited career prospects is brought home to him when Mansourian, who by coincidence lives in the same apartment building as Paul's new lover, bumps into Paul in the elevator and invites him, once again, to be the page turner - but this time for a fourteen-year old musical prodigy who is the star pupil at Paul's academy. Paul agrees, only to end up having sex with Mansourian, mainly because of the emotions produced by discovering the photographic presence of Kennington in Mansourian's apartment, which brings memories of their idyll in Barcelona flooding back.

\section{Notes to \# 3 :}

New York is the city that will act as a catalyst for Paul's barsh awakening to reality. Both love and life are not as simple as be bad thought, and Paul has to face the intricate implications of his situation. The good thing about Paul is that be is capable of coming to grips with the fact that his life is not going to be as be, and all the people who once surrounded him in California, had hoped.

The winter light of New York, so different from the Mediterranean warmth of the previous act, will be an important element in Paul's "journey" back down to earth. Finally aware of the competitive ethos of the higher echelons of the artistic life that he had so desired, Paul also recognizes the fragility of the affairs of the beart. These parallel disappointments make him grow into a man.

\section{Four}

Back home in California for Christmas, Paul confides to his mother that he is thinking of abandoning his musical career, that there are perhaps other things in life. Devastated, and struggling to understand the change in her son's attitude, she rifles through his personal belongings. Among a number of objects that indicate that Paul is gay she comes across a photograph of Kennington with a terse love note written on the back. In fact, Paul had stolen the photograph when he was in Mansourian's apartment, but Pamela jumps to the wrong conclusion and blames Kennington for Paul's decision to abandon music and believes, moreover, that they are continuing their affair in 


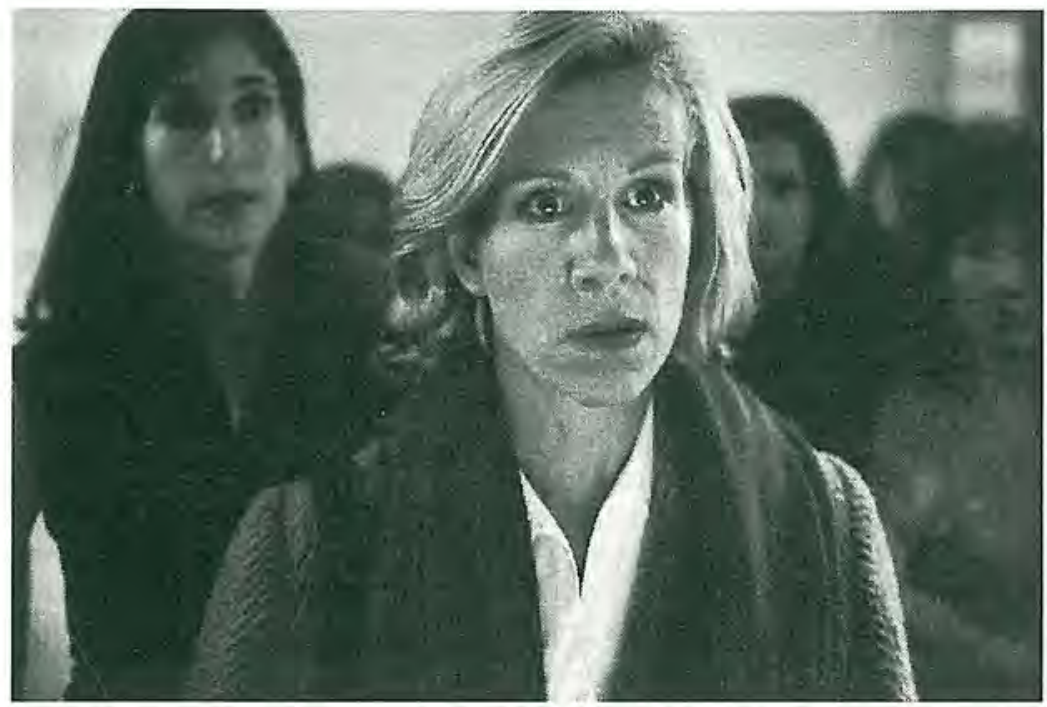

Juliet Stevenson as Pamela

New York. Pamela attends a group therapy session for the mothers of homosexual sons in an attempt to come to terms with her discovery.

\section{Notes to \# 4 :}

This act sees Pamela's awakening to Paul's reality, which allows ber, interestingly enough, to confront her own innermost emotions. In a certain sense, the film thus reveals a double awakening: of both mother and son. Finally able to act as a man and to face the consequences of bis decisions, Paul acts bravely, in contrast with the moral cowardice that Kennington, riddled with fear, had demonstrated in Act 2. Pamela and $P$ aul are now acting as autonomous adults and no longer merely as a mother and son unit. The umbilical cord has most definitely been severed. Pamela realizes that her situation is by no means unusual and that she is not alone in the world. This gives her the strength to travel to New York alone, to confront Kennington, and to fight for ber son.

\section{Five}

Determined to give a piece of her mind to the man she deems responsible for ruining her son's brilliant career, Pamela challenges 
Kennington, but only to realize things are not as she had thought. She arrives at Kennington's apartment, where a party is happening, and proceeds to make a fool of herself. Mansourian informs Pamela as to where she may find Paul: at a dinner party at Alden's. A tense telephone conversation ensues.

Pamela's accusations have revealed the nature of both Mansourian and Kennington's dealings with Paul. After their guests have left, Kennington and Mansourian talk about the "forbidden fruit" that they have both tasted. "If music be the food of love, play on..." Mansourian makes sure that Kennington believes that Paul is of no importance and thus ensures that the boat of their contented existence together will not be rocked. Paul leaves the dinner at Alden's to meet his mother at his apartment. Although he is terribly embarrassed by his mother's behavior and irritated by her presumptuous interference, he initiates what turns out to be a profound, heartfelt conversation in which home truths are brought to the fore. Mother and son both have to face the end of their dreams, but they have grown from the experience and are able to accept their own lives and each other as they really are.

\section{Notes to \# $5:$}

The denonement of the story takes us to New York once again, the city where a number of hard, but necessary, truths are revealed. Kennington and Mansourian's established world, along with their frivolous and cynical behavior, appear more and more self-contained and distant from Pamela and Paul's intensely frank reencounter. Mother and son lay the grounds for a new life for both of them - a life not spectacular, but at least honest and real. Will it come to fruition? Will it be possible? The film raises these questions, and leaves them, tantalizingly, unanswered.

VENTURA PONS

\section{WORKS CITED}

SHAKESPEARE, William. Twelfth-Night: Or, What You Will. The Illustrated Stratford Shakespeare. New York: Exeter Books (Simon \& Schuster), 1984-289-3Ir. 